\title{
Selection of Novel Cowpea Genotypes Derived through Gamma Irradiation
}

\author{
Lydia N. Horn ${ }^{1,2}$, Habteab M. Ghebrehiwot ${ }^{1,3 *}$ and Hussein A. Shimelis ${ }^{1,3}$ \\ ${ }^{1}$ School of Agricultural, Earth and Environmental Sciences, College of Agriculture, Engineering and Science, University of \\ KwaZulu-Natal, Pietermaritzburg, South Africa, ${ }^{2}$ Directorate of Research and Training, Plant Production Research, Ministry \\ of Agriculture, Water and Forestry, Windhoek, Namibia, ${ }^{3}$ African Centre for Crop Improvement, University of KwaZulu-Natal, \\ Pietermaritzburg, South Africa
}

Cowpea (Vigna unguiculata [L.] Walp.) yields are considerably low in Namibia due to lack of improved varieties and biotic and abiotic stresses, notably, recurrent drought. Thus, genetic improvement in cowpea aims to develop cultivars with improved grain yield and tolerance to abiotic and biotic stress factors. The objective of this study was to identify agronomically desirable cowpea genotypes after mutagenesis using gamma irradiation. Seeds of three traditional cowpea varieties widely grown in Namibia including Nakare (IT81D-985), Shindimba (IT89KD-245-1), and Bira (IT87D-453-2) were gamma

OPEN ACCESS

Edited by:

Oswaldo Valdes-Lopez, National Autonomous University of Mexico, Mexico

Reviewed by:

Karthika Rajendran, International Center for Agricultural Research in the Dry Areas, Morocco

Minviluz Garcia Stacey, University of Missouri, USA

${ }^{*}$ Correspondence: Habteab M. Ghebrehiwot ghebrehiwoth@ukzn.ac.za

Specialty section: This article was submitted to Crop Science and Horticulture, a section of the journal Frontiers in Plant Science

Received: 23 November 2015 Accepted: 19 February 2016 Published: 10 March 2016

Citation:

Horn LN, Ghebrehiwot HM and Shimelis HA (2016) Selection of Novel Cowpea Genotypes Derived through Gamma Irradiation.

Front. Plant Sci. 7:262. doi: 10.3389/fpls.2016.00262 irradiated with varied doses and desirable mutants were selected from $\mathrm{M}_{2}$ through $M_{6}$ generations. Substantial genetic variability was detected among cowpea genotypes after mutagenesis across generations including in flowering ability, maturity, flower and seed colors and grain yields. Ten phenotypically and agronomically stable novel mutants were isolated at the $M_{6}$ each from the genetic background of the above three varieties. The selected promising mutants' lines are recommended for adaptability and stability tests across representative agro-ecologies for large-scale production or breeding in Namibia or similar environments. The novel cowpea genotypes selected through the study are valuable genetic resources for genetic enhancement and breeding.

Keywords: cowpea, gamma radiation, mutation breeding, mutants, legume improvement

\section{INTRODUCTION}

Cowpea (Vigna unguiculata L. Walp.) is a leguminous species used as food, forage, and vegetable crop mainly in the tropics (Steele, 1972). The grains are an excellent source of food and feed; a vital nutrient for healthy growth both for humans and livestock. The leaves, green pods, and grains are consumed as a dietary source of protein (Ghaly and Alkoaik, 2010). The cowpea grain contains $23 \%$ protein and $57 \%$ carbohydrate, and the leaves contain $27-34 \%$ of proteins. The crop originated and domesticated in Southern Africa, which was later spread to east and West Africa and Asia (International Institute for Tropical Agriculture [IITA], 2004). In semi-arid West and Central Africa, it is consumed as a pulse where it supplements the daily diet (Bressani, 1985). Thus, cowpea production remains the most prominent food legume cultivated by farmers majorly in most subSaharan African countries. The main reasons being the natural ability of the crop to withstand moderate episodes of drought and its adaptation to grow in nutrient limited soils. Cowpea is also able to fix atmospheric nitrogen in marginal soils where farmers are unable to adequately fertilize 
their crops due to unaffordability or inaccessibility (Steele, 1972). Accounts indicate that greater than 16,000 genotypes of cowpea are registered in trust for the World Bank by the International Institute of Tropical Agriculture, (IITA) Ibadan, Nigeria. Such a huge genotype bank is believed to provide a wide range of information on the agronomy and potential benefits of the crop.

The southern African region is reportedly considered the centre of diversity of $V$. unguiculata which includes Namibia, Botswana, Zambia, Zimbabwe, Mozambique, and the Republic of South Africa ( $\mathrm{Ng}$ and Marachel, 1985). In Namibia, cowpea is the second most important crop next to pearl millet. Nearly, 95\% of the smallholder farmers in the northern part of the country grow cowpea for food security and/or livelihoods. However, cowpea yields of the available cultivars are considerably low (250-350 kg/ha) predominantly due to lack of improved varieties and biotic and abiotic stresses notably recurrent severe drought. Hence, genetic improvement in cowpea requires systematic breeding and development of genotypes associated with higher yielding capacity and drought resilience.

Genetic variation is the basis for plant breeding programs. Most conventional crop improvement programs rely on natural genetic variation present among germplasm pools (Ceccarelli and Grando, 2007). Mutations can be induced in various ways, such as exposure of plant propagules, including seeds, tissues, and organs, to physical and chemical mutagens (Mba et al., 2010). Induced mutagenesis has the potential to create genetic variation for genetic enhancement and breeding in a relatively shorter time unlike natural mutation or controlled crosses of especially unrelated parents (Singh et al., 2006; Wani, 2006; Tulmann Neto et al., 2011). Gnanamurthy et al. (2012) reported that induced mutations have been successfully used in breeding of seed propagated crops since 1940s. The Mutant Varieties Database (MVD) of FAO (Food and Agriculture Organisation of the United Nations) and the International Atomic Energy Agency (IAEA) maintained a list of 2,252 crop cultivars developed through artificial mutations (Nielen, 2004). These cultivars were released across 59 countries worldwide, mainly in the continental Asia (1,142 cultivars), Europe (847), and North America (160) (Maluszynski, 2001; Maluszynski et al., 2009). Studies indicate that induced mutagenesis has successfully modified several plant traits such as plant height, maturity, seed shattering resistance, disease resistance, oil quality and quantity, malting quality, size and quality of starch granules of cowpea (Goyal and Khan, 2010; Singh et al., 2013).

In South Africa, cowpea mutants were developed through selections from the $M_{2}$ to $M_{4}$ generations. These included the drought tolerant mutants such as 447,217 , and 346 , and mutants such as 447, MA2, and 217 isolated for their high yielding ability under well-watered conditions (De Ronde and Spreeth, 2007). Furthermore, early maturing cowpea mutants with leaflets containing tendrils, broad leaves, and light green pods were developed through gamma irradiation in Nigeria (Adekola and Oluleye, 2007). The use of gamma irradiation at different doses has been reported to change the proximate and anti-nutritive compositions in pulses (Udensi et al., 2012). Some varieties of groundnut were developed in Congo through gamma irradiation (Tshilenge-Lukanda et al., 2012). Wani (2006) reported a significant increase in the mean values of the fertile branches per plant, pods per plant and seed yield per plant (SYP) in mutant varieties of mungbean (Vigna radiata [L.] Wilczek) derived through gamma irradiation.

In light of this, a collaborative research was developed in 2009 between the Namibian Government and the IAEA under Technical Cooperation project on induced mutation breeding using Gamma irradiation. This created a platform for prebreeding and breeding of high yielding, drought tolerant and insect pest resistant genotypes of cowpea. Gamma irradiation was recommended by the Namibian Radiation Regulatory Authority as an alternative option to create new crop genotypes in a short period of time without any negative impact to the environment.

Therefore, the objective of this study was to identify desirable cowpea genotypes after gamma irradiation of three traditional cowpea varieties widely grown in Namibia including Nakare (IT81D-985), Shindimba (IT89KD-245-1), and Bira (IT87D453-2) through continuous selections from $\mathrm{M}_{2}$ through $\mathrm{M}_{6}$ generations.

\section{MATERIALS AND METHODS}

\section{Plant Material and Gamma Irradiation}

Three cowpea genotypes widely grown in Namibia, namely, Nakare (IT81D-985), Shindimba (IT89KD-245-1) and Bira (IT87D-453-2) were obtained from Likorerere Farmers Cooperatives at Kavango Region, Namibia. The seeds were irradiated at the International Atomic Energy Agency (IAEA), Agriculture and Biotechnology Laboratory, A-2444 Seibersdorf, Austria using a CO60 source Gammacell Model No. 220. Various doses were used to establish the optimum irradiation level that can achieve optimum mutation frequency with least possible and unintended damage. The three varieties were gamma irradiated as follows: Bira $[0,75,150,300,450$, and 600 Gy], Nakare [0, $100,150,200,250$, and $300 \mathrm{~Gy}]$ and Shindimba $[0,100,150$, 200, 300, and $400 \mathrm{~Gy}$ ]. Preliminary tests showed that the three varieties differed in their optimal requirement of irradiation doses and was used as the bases for using different doses for each genotype (Horn and Shimelis, 2013). The 0 Gy dose served as a comparative control.

\section{Study Sites, Experimental Design, and Field Establishment}

A series of selection experiments were conducted at three different sites; namely Mannheim, Bagani, and Omahenene. Mannheim Research Station is located in Oshikoto region along the north central of Namibia and it is situated at an altitude of $1234 \mathrm{~m}$ above sea level (masl). Bagani Research Station is located at (1007 masl) north east in the Kavango East region, whereas Omahenene research station is situated in the Omusati Region in North-Western Namibia at altitude of 1109 masl. In general, climatic, biological conditions of the selection sites vary considerably. Physicochemical properties of the sites are provided in Table 1. The $M_{1}$ and $M_{2}$ generations were evaluated at Mannheim Research Station during the 2009/2010 and 2010/2011 seasons, respectively. The $\mathrm{M}_{3}$ generations were established at 
TABLE 1 | Physicochemical properties of soils at Mannheim, Bagani, and Omahenene research sites in Namibia.

\begin{tabular}{lccc}
\hline Sample/parameter & \multicolumn{2}{c}{ Research Station (study site) } \\
\cline { 2 - 4 } & Mannheim & Bagani & Omahenene \\
\hline Soil pH & 7.87 & 7.5 & 8.2 \\
Total Nitrogen\% & 0.06 & 0.06 & 0.05 \\
Organic carbon\% & 0.38 & 0.48 & 0.60 \\
Phosphorus (ppm) & 18 & 58.2 & 14 \\
Potassium me\% & 0.17 & 0.9 & 0.99 \\
Calcium me \% & 1.6 & 1.3 & 1.38 \\
Magnesium me\% & 4.74 & 1.7 & 4.80 \\
Manganese me\% & 0.05 & 0.18 & 0.17 \\
Copper (ppm) & 0.6 & 0.6 & 0.5 \\
Iron (ppm) & 0.5 & 0.7 & 0.5 \\
Zinc (ppm) & 0.6 & 0.5 & 0.4 \\
Sodium \% & 0.10 & 0.09 & 0.07 \\
EC mS/cm & 0.29 & 0.18 & 0.36 \\
\hline Ppm partper & & &
\end{tabular}

ppm, part per million; me, milliequivalent; EC, electrical conductivity.

Bagani research station during the 2011/2012 season. The $\mathrm{M}_{4}$ and $\mathrm{M}_{5}$ were established at Omahenene Research Station in 2012/2013 and 2013/2014 season, respectively.

Plots were arranged in a randomized complete block design using two replications. Plants were established using intra-row spacing of $20 \mathrm{~cm}$ and inter-row spacing of $75 \mathrm{~cm}$. Seedlings were thinned to one plant per hill after 2 weeks from planting. Weeds were controlled manually. Planting of the $\mathrm{M}_{1}$ seeds was done under normal growing conditions with supplemental irrigation during dry spell. Each row of the $\mathrm{M}_{1}$ generation contained 26 individuals, making a total of 104 plants per irradiation dose. At harvest the $\mathrm{M}_{2}$ seeds were bulked in separate bags according to irradiation doses (Figure 1). During the $\mathrm{M}_{2}$ to $\mathrm{M}_{5}$ generations' variable number of individual plants ranging from 50 to 100 per irradiation dose were assayed for qualitative and quantitative observations.

\section{Selection Procedure and Data Collection}

The selection procedure was undertaken based on methods adapted from Maluszynski et al. (2009). The selection procedure used in the study is illustrated in Figure 1. The irradiated seeds $\left(\mathrm{M}_{1}\right)$ were planted in the field at Mannheim research station under standard cultural practices. All the pods, from the $M_{1}$ plants that survived were harvested and bulked according to their respective radiation doses and genotypes. Consequently, the harvested $\mathrm{M}_{2}$ seeds were planted in the field at Mannheim as $\mathrm{M}_{2}$ population during 2010/2011 season in the form of progeny rows for individual plant selection and to develop the $M_{3}$ seeds. The $M_{3}$ seed from selected $M_{2}$ plants were planted at Omahenene and Bagani Research Station during 2011/2012 for evaluation. The $\mathrm{M}_{3}$ plants at both sites were evaluated in the field using morphological and agronomical attributes. Pods from selected $M_{3}$ plants were harvested. During 2012/2013, the $\mathrm{M}_{4}$ seeds obtained from the selected $\mathrm{M}_{3}$ population were planted at Omahenene Research Station as single-plant progenies and segregants were selected with desired traits. During 2013/2014 the $\mathrm{M}_{5}$ seeds obtained from the selected $\mathrm{M}_{4}$ population were planted at Omahenene Research Station as single-plant progenies and selection were made toward desired trait on single plant basis. Uniform, non-segregating mutant progenies, were bulked at this stage to hasten the breeding cycle. During 2014/2015 the $\mathrm{M}_{6}$ generation was evaluated at Omahenene, Bagani, and Mannheim using suitable lines selected for seed yield and related traits.

\section{Data Collection and Analysis}

Both quantitative and qualitative data were collected during evaluations from the $\mathrm{M}_{2}$ to $\mathrm{M}_{5}$ generations. The data collected included: days to $50 \%$ germination (DG), percent seed emergence (ES\%), number of abnormal individuals or visual phenotype mutants $(\mathrm{ABN})$, total number of surviving plants per plot (TNP), number of main branches (NMB) averaged over 10 randomly selected and tagged plants, days to $50 \%$ flowering (DTF), days to $50 \%$ pod setting (DPS), days to $50 \%$ maturity(DMT), number of pods per plant (NPP) averaged over five pods per selected plant, pod length (PL) expressed in $\mathrm{cm}$ and averaged over five pods per plant, pod weight per plant (PW) in gram, number of seeds per pod (NSP) averaged over five pods per plant, 100 seed weight (HSW) in gram and SYP in gram. The qualitative data collected included variation in flower color (FC) and seed color (SC) during the $\mathrm{M}_{1}$ and $\mathrm{M}_{2}$ generations. Additional qualitative data such as, pod shape (PS), pod color (PC), seed coat texture (SCT), and growth habit $(\mathrm{GH})$ were collected from $\mathrm{M}_{2}$ to $\mathrm{M}_{5}$ generations. Data were analyzed and descriptive statistics summarized using the SAS statistical program (SAS, 2002).

\section{RESULTS}

\section{Phenotypic Characterization of Mutants Qualitative and Quantitative Traits at $M_{1}$ and $M_{2}$}

During the $M_{1}$ and $M_{2}$ generations the percentage field establishment (ES) ranged between 79 to $89 \%$, respectively (Table 2). Nakare and Shindimba mutants had ES of $0 \%$ at irradiation does of 250, 300, and 400 Gy. Phenotypic abnormalities such as albinism, leaf deformity, single stem, seedless pods or short pod sizes were invariably observed at the following doses and genotypes: 450 and 600 Gy (Bira); 150 and 200 Gy (Nakare); and 100, 150, and 200 Gy (Shindimba) (Figure 2). Segregation of FC (white and purple) were observed at the $\mathrm{M}_{2}$ with the following doses and genotypes: 300, 450, and 600 Gy (Bira), 100 and 200 Gy (Nakare), and 100, 150, and 200 Gy (Shindimba) (Figure 3). SC variations were observed during the $\mathrm{M}_{2}$ (Figure 4). White, brown, red, and cream SC were common in Bira mutants across all irradiation doses. In addition to these Nakare and Shindimba had speckled, chocolate, light brown, black, mixed and dark brown SC when subjected to irradiation doses of 100, 150, and 200 Gy (Table 2 and Figure 4). Bira mutants displayed relatively high seed yields varying from 98 to $200 \mathrm{~g} /$ plant at 0 and $600 \mathrm{~Gy}$, respectively (Table 2).

\section{Qualitative Traits Evaluated during the $\mathrm{M}_{\mathbf{3}}$ to the $\mathbf{M}_{\mathbf{5}}$}

Variable number of individual plants was available for selection during $\mathrm{M}_{3}$ to $\mathrm{M}_{5}$ generations, because of the strength of 


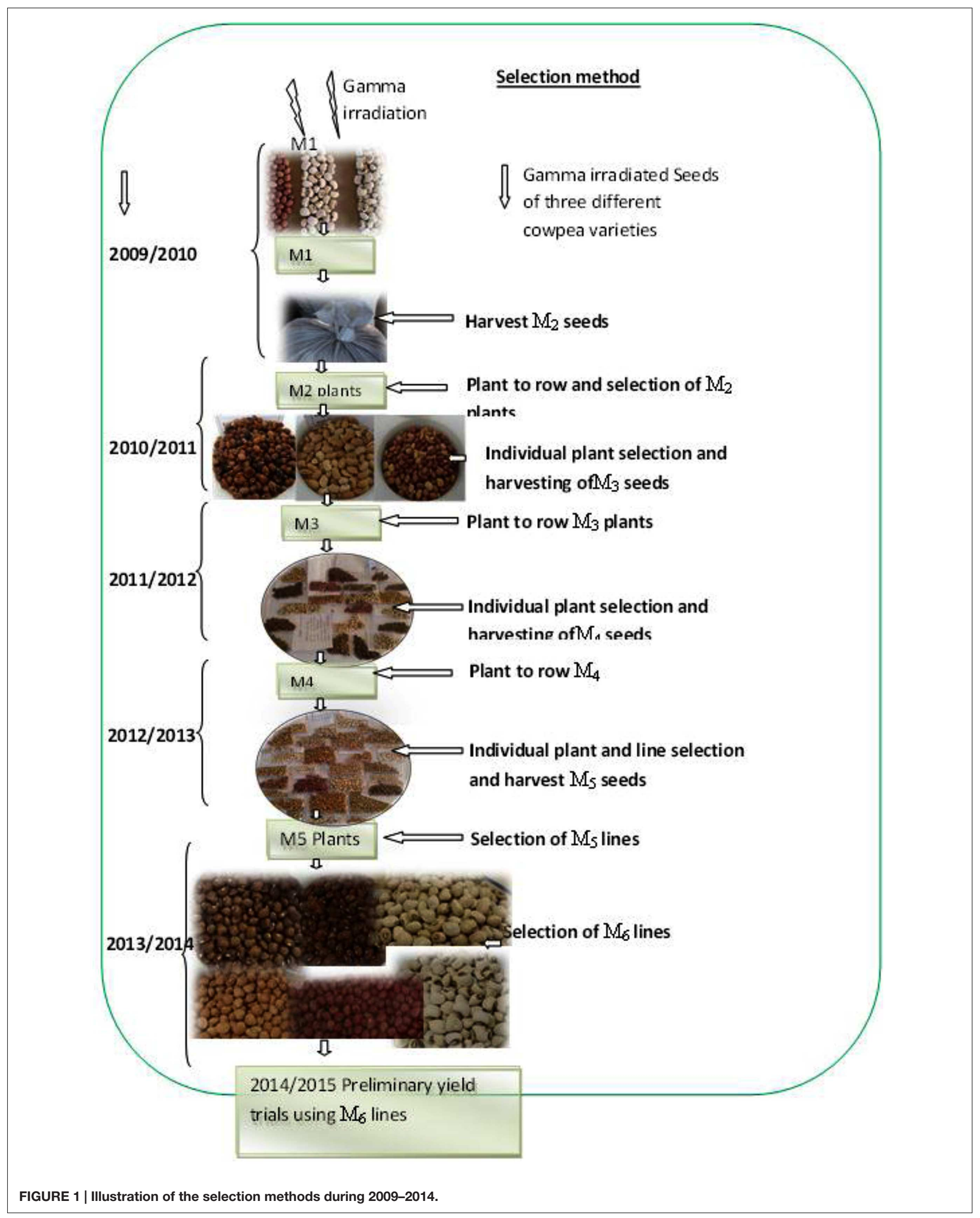


TABLE 2 | Phenotypic characteristics of mutants observed during the first two seasons 2009/2010 and 2010/2011 at Mannheim Research Station.

\begin{tabular}{|c|c|c|c|c|c|c|c|c|c|c|c|}
\hline \multirow[t]{2}{*}{ Variety } & \multicolumn{6}{|c|}{$M_{1}(2009 / 2010)$} & \multicolumn{5}{|c|}{$M_{2}(210 / 2011)$} \\
\hline & Dose (Gy) & ES\% & ABN & FC & SC & SYP & ES\% & ABN & FC & sc & SYP \\
\hline \multirow[t]{6}{*}{ Bira } & 0 & 89 & 0 & 2 & 3 & 2.9 & 99 & 0 & 2 & 3 & 98 \\
\hline & 75 & 80 & 0 & 2 & 3 & 2.9 & 88 & 0 & 2 & $1,2,3,4$ & 150 \\
\hline & 150 & 87 & 0 & 2 & 3 & 3.1 & 89 & 0 & 2 & $1,2,3,4$ & 162 \\
\hline & 300 & 82 & 1 & 2 & 3 & 2.0 & 90 & $1,2,3$ & 1,2 & $1,2,3,4$ & 160 \\
\hline & 450 & 81 & 1,2 & 2 & 3 & 1.6 & 93 & $1,2,3$ & 1,2 & $1,2,3,4$ & 158 \\
\hline & 600 & 79 & $1,2,3,4,5$ & 2 & 3 & 1.1 & 97 & $1,2,3,5$ & 1,2 & $1,2,3,4$ & 200 \\
\hline \multirow[t]{6}{*}{ Nakare } & 0 & 86 & 0 & 1 & 1 & 1.6 & 89 & 0 & 1 & 1 & 90 \\
\hline & 100 & 49 & 0 & 1 & 1 & 1.3 & 88 & 0 & 1,2 & $1,2,4,5,6$ & 75 \\
\hline & 150 & 46 & $1,2,3,4$ & 1 & 1 & 0.3 & 86 & $1,2,3$ & 1,2 & $1,2,4,5,6$ & 81 \\
\hline & 200 & 8 & $1,2,3,4$ & 1 & 1 & 0.5 & 80 & $1,2,3,4,5$ & 1,2 & $1,2,4,5,6$ & 71 \\
\hline & 250 & 0 & $\mathrm{~N} / \mathrm{A}$ & $\mathrm{N} / \mathrm{A}$ & $\mathrm{N} / \mathrm{A}$ & 0.0 & N/A & $\mathrm{N} / \mathrm{A}$ & $\mathrm{N} / \mathrm{A}$ & $\mathrm{N} / \mathrm{A}$ & $\mathrm{N} / \mathrm{A}$ \\
\hline & 300 & 0 & N/A & $\mathrm{N} / \mathrm{A}$ & N/A & 0.0 & N/A & N/A & N/A & $\mathrm{N} / \mathrm{A}$ & N/A \\
\hline \multirow[t]{6}{*}{ Shindimba } & 0 & 88 & 0 & 1 & 1 & 1.9 & 95 & 0 & 1 & 1 & 70 \\
\hline & 100 & 35 & $1,2,3,4$ & 1 & 1 & 1.4 & 86 & $1,2,3$ & 1,2 & $1,2,4,5,6$ & 66 \\
\hline & 150 & 37 & $1,2,3,4$ & 1 & 1 & 0.8 & 93 & $1,2,3$ & 1,2 & $1,2,4,5,6$ & 65 \\
\hline & 200 & 18 & $1,2,3,4$ & 1 & 1 & 0.1 & 90 & $1,2,3,4,5$ & 1,2 & $1,2,4,5,6$ & 60 \\
\hline & 300 & 0 & $\mathrm{~N} / \mathrm{A}$ & $\mathrm{N} / \mathrm{A}$ & $\mathrm{N} / \mathrm{A}$ & $\mathrm{N} / \mathrm{A}$ & $\mathrm{N} / \mathrm{A}$ & $\mathrm{N} / \mathrm{A}$ & $\mathrm{N} / \mathrm{A}$ & $\mathrm{N} / \mathrm{A}$ & N/A \\
\hline & 400 & 0 & $\mathrm{~N} / \mathrm{A}$ & $\mathrm{N} / \mathrm{A}$ & N/A & N/A & N/A & N/A & $\mathrm{N} / \mathrm{A}$ & N/A & N/A \\
\hline
\end{tabular}

ES\%, establishment in \%; ABN, abnormalities observed, where $0=$ normal, $1=$ albino, $2=$ leafy type, $3=$ upright single stem, $4=$ seedless pods, and $5=$ short pods; FC, flower color, where $1=$ white, $2=$ purple. SC, seed color; where $1=$ white, $2=$ brown, $3=$ red, $4=$ cream, $5=$ speckled, $6=$ chocolate, $7=$ light brown, $8=$ black, $9=$ mixed, $10=$ dark brown. SYP, seed yield (gram/plant).

irradiation treatment and segregation. The following doses allowed successful selections of mutants during the $M_{3}$ to $M_{5}$ : 300, 450, and 600 Gy (Bira), 100 and 150 Gy (Nakare), and 100 and 200 Gy (Shindimba). Surviving and phenotypically stable individuals were advanced at each selection generation at Omahenene and Bagani Research Stations. Qualitative traits had limited variation during $\mathrm{M}_{3}$ to $\mathrm{M}_{5}$ (Table 3). Bira mutants displayed purple FC irrespective of doses and test generations, while Nakare and Shindimba segregated for white and purple FC (Figures 3 and 5). Both Bira and Nakare mutants had straight PS similar to the controls. However, Shindimba segregants had straight and coiled pod types (Figure 5). Variable SCs including white, brown, red, cream, speckled, chocolate, light and dark brown, black and mixed were observed during the $M_{3}$ to $M_{5}$. Bira mutants had smooth SCT, while Nakare and Shindimba had mainly rough and smooth seed texture. Bushy, erect and spreading GHs were detected during the $\mathrm{M}_{3}$ to $\mathrm{M}_{5}$ (Figures 3 and 5).

\section{Quantitative Traits Observed from $M_{3}$ to $M_{5}$}

Quantitative traits of agronomic importance were measured during the $\mathrm{M}_{3}$ to $\mathrm{M}_{5}$ (Table 4). The percent seed emrgence (ES\%) reduced significantly with increased irradiation dose. Maximum seed germination was achieved 3 days after planting irrespective of irradiation doses (Tables 4-6). Shindimba mutants relatively flowered early (40 days) at the $\mathrm{M}_{3}$ (Table 4).

At the $\mathrm{M}_{4}$ a relatively shorter days to flowering (44 days) was recorded at $300 \mathrm{~Gy}$ (Table 5). Contrastingly, the number of days to flowering was 37 days at the $\mathrm{M}_{5}$ at using $600 \mathrm{~Gy}$ (Table 6). Nakare derived mutants flowered relatively earlier
(10 days) at $100 \mathrm{~Gy}$ at the $\mathrm{M}_{3}$ (Table 4). At the $\mathrm{M}_{5}$ Nakare mutants recorded a minimum of 61 days to flowering at 0 and 150 Gy (Table 5). At the $\mathrm{M}_{3}$, Shindimba mutants displayed a minimum of 15 and a maximum of 84 days to flowering at 200 and 100 Gy, respectively (Table 4). Nakare mutants recorded the lower days (25) for pod setting (DPS) at the $\mathrm{M}_{3}$ when using 100 Gy. Comparatively, the higher number of DPS (98 days) was measured in Shindimba at 200 Gy. At the $M_{4}$ a minimum DPS of 48 days was recorded for Bira derivatives at $300 \mathrm{~Gy}$. A maximum DPS of 86 days was recorded for Bira mutants at $400 \mathrm{~Gy}$, Nakare at 100 and $150 \mathrm{~Gy}$ and Shindimba at 100 and 200 Gy (Table 5). At the $\mathrm{M}_{5}$, Nakare mutants recorded the lower DPS (41 days) at $100 \mathrm{~Gy}$, while Bira genotypes had the higher DPS of 88 days at 300 Gy, Table 6). During the M3, Nakare mutants matured 32 days after planting at 100 Gy. At the same dose rate Shindimba displayed late maturity (98 days) at the $M_{3}$ (Table 4). During the $M_{4}$ Bira mutants matured earlier (54 days) at 450 Gy. Delayed maturity (115 days) were recorded for Nakare at $150 \mathrm{~Gy}$ and Shindimba at 100 and 200 Gy (Table 5). At the $\mathrm{M}_{5}$ Bira measured early maturity (62 days) with the highest dose of $600 \mathrm{~Gy}$. Interestingly, this genotype matured late (115 days) when subjected to irradiation dose of 300 Gy (Table 6). Nevertheless, Bira recorded lower NPP (1 pod/plant) at $600 \mathrm{~Gy}$ and higher (5 pods/plant) when irradiated at $300 \mathrm{~Gy}$ (Table 4). At the $\mathrm{M}_{4}, 1$ pod/plant was recorded for Bira at 450 and $600 \mathrm{~Gy}$ and Shindimba at $200 \mathrm{~Gy}$ (Table 5).

At the $\mathrm{M}_{3}$ the longer pod size measured at $23.5 \mathrm{~cm}$ was recorded for Nakare at $100 \mathrm{~Gy}$ (Table 4). At the $\mathrm{M}_{4}$, Shindimba mutants resulted from 200 Gy measured longer pod size of 


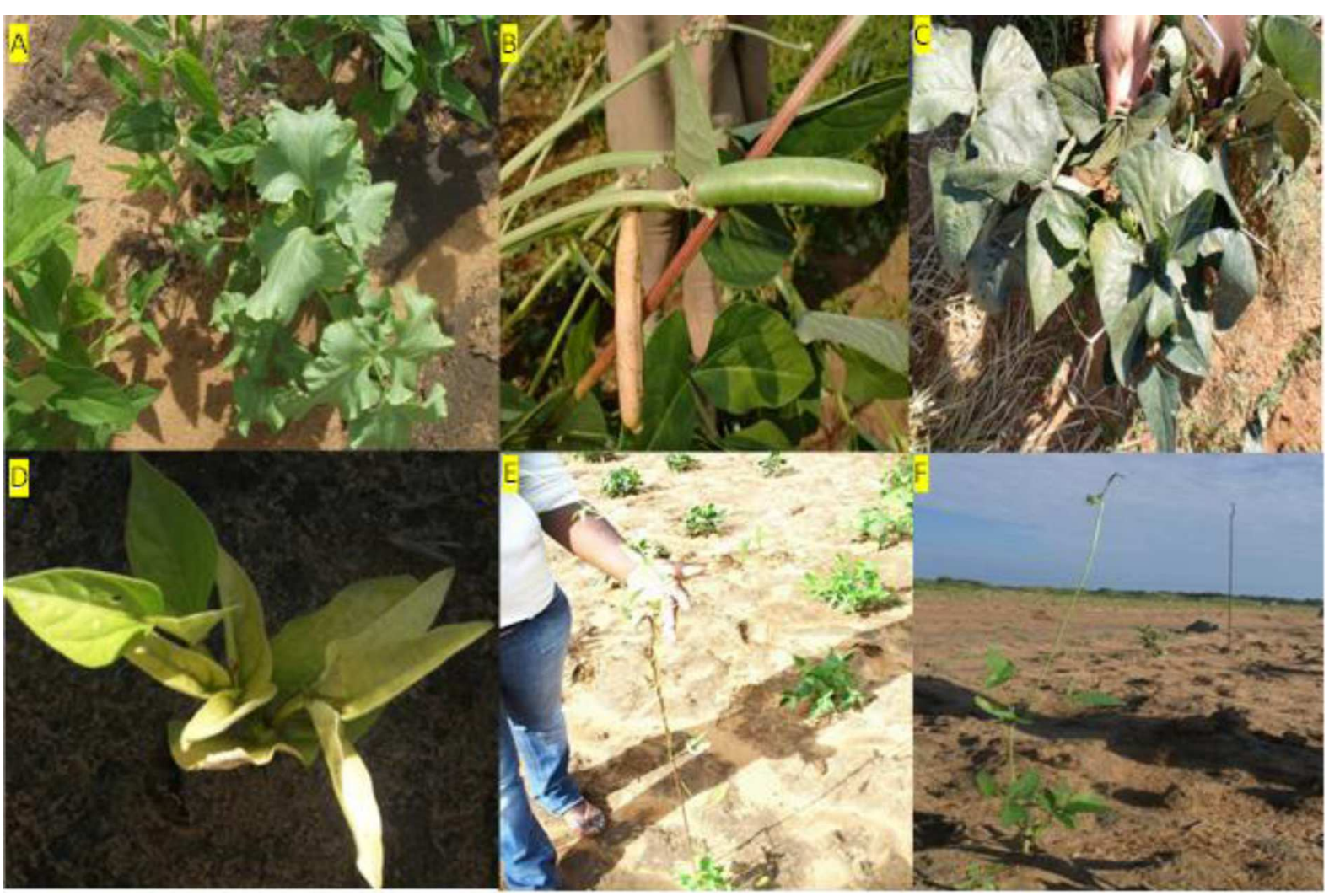

FIGURE 2 | Some common abnormalities at $\mathbf{M}_{\mathbf{3}}$ observed at Bagani Research Station. (A) spinach-like leaves, (B) Short-pods, (C) broad-dark leaves, (D) chlorophyll mutant, -single stem (E,F) observed at Omahenene research Station.

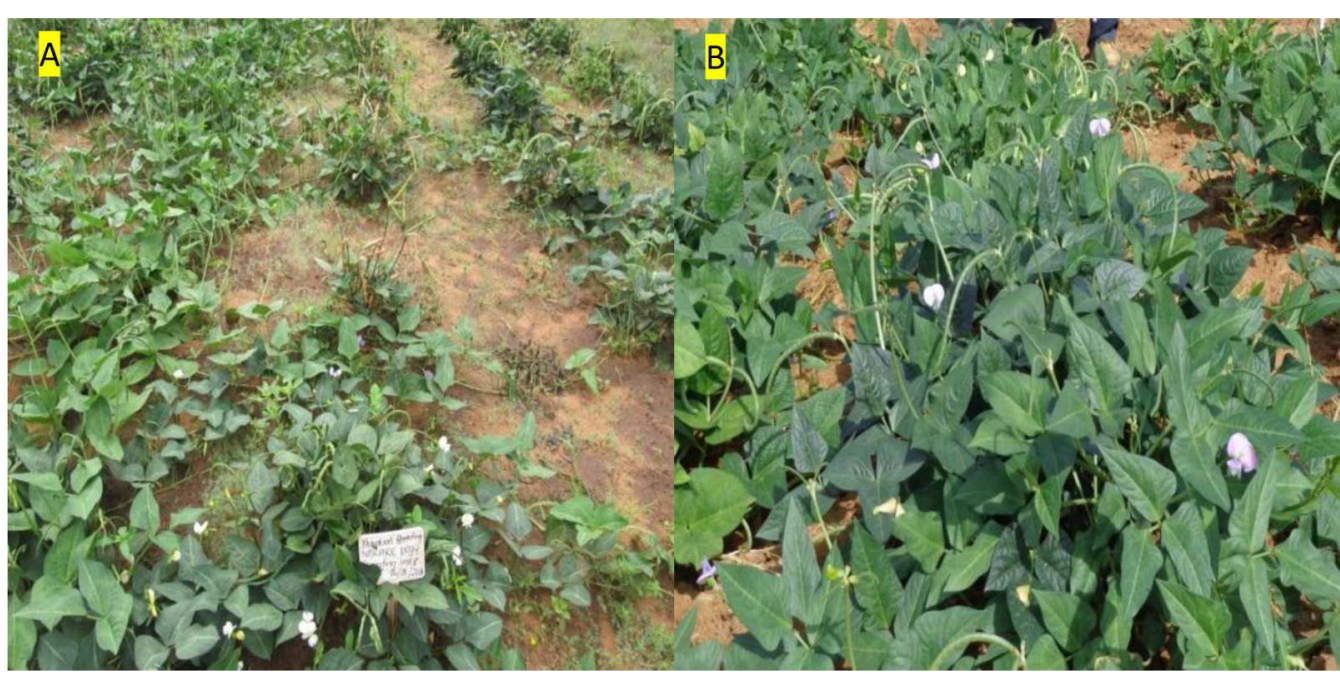

FIGURE 3 | Variation in flower color (A) white flower color, (B) purple flower and field plant stands of $\mathbf{M}_{5}$ Nakare mutants observed at Omahenene Research Station in Namibia.

$31 \mathrm{~cm}$ (Table 5). Bira mutants induced with 300 Gy produced longer pod size $(30 \mathrm{~cm})$ (Table 6). Relatively heavier pod size (4003 g/plant) was recorded for Bira at $300 \mathrm{~Gy}$ (Table 4). At the M4, Bira had pod size measured at $325 \mathrm{~g} / \mathrm{plant}$ at $300 \mathrm{~Gy}$. Notably this genotype had reduced pod weight $(1 \mathrm{~g} /$ plant $)$ at the highest irradiation dose (Table 5).

The NSP varied significantly between irradiation doses and genotypes. At the $\mathrm{M}_{3}$, the highest number of seeds of 18.6/pod 


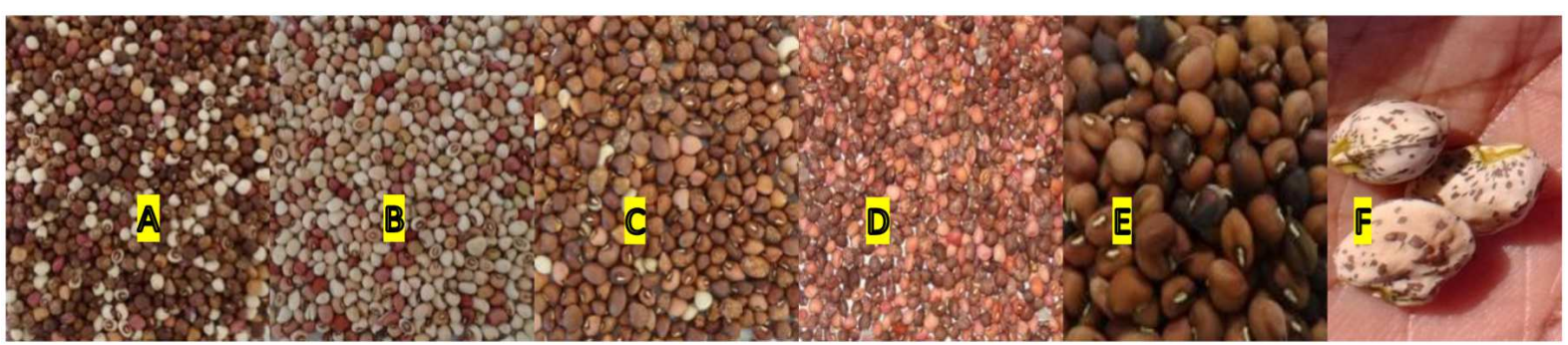

FIGURE 4 | Different $M_{3}$ seed colors (A-F) observed among all mutants at all locations.

TABLE 3 | Qualitative traits observed among the mutant lines at the $\mathbf{M}_{3}, \mathbf{M}_{4}$, and $\mathbf{M}_{5}$ at Omahenene and Bagani Research Stations.

\begin{tabular}{|c|c|c|c|c|c|c|c|}
\hline Genotype & Dose (Gy) & FC & PS & PC & SC & SCT & GH \\
\hline \multirow[t]{4}{*}{ Bira } & 0 & 2 & 1 & 1 & 3 & 1 & 3 \\
\hline & 300 & 2 & 1 & 1 & $1,2,3,4$ & 1 & $1,2,3$ \\
\hline & 450 & 2 & 1 & 1 & $1,2,3,4$ & 1 & $1,2,3$ \\
\hline & 600 & 2 & 1 & 1 & $1,2,3,4,5,6,7,8$ & 1 & $1,2,3$ \\
\hline \multirow[t]{3}{*}{ Nakare } & 0 & 1 & 1 & 1 & 1 & 2 & 2 \\
\hline & 100 & 1,2 & 1 & 1 & $1,2,3,6,7,9,10$ & 1,2 & 1,2 \\
\hline & 150 & 1,2 & 1 & 1 & $1,2,3,6,7,9,10$ & 1,2 & 1,2 \\
\hline \multirow[t]{3}{*}{ Shindimba } & 0 & 1 & 2 & 1 & 1 & 1,2 & 2 \\
\hline & 100 & 1,2 & 1,2 & 1 & $1,2,3,7,9,10$ & 1,2 & 1,2 \\
\hline & 200 & 1,2 & 1,2 & 1 & $1,2,3,7,9,10$ & 1,2 & 1,2 \\
\hline
\end{tabular}

FC, flower color, where 1 = white, 2 = purple; PS, pod shape, where 1 = straight, 2 = coiled or curved; PC, pod color, where $1=$ cream; SC = seed color, where $1=$ white, 2 = brown, $3=$ red, $4=$ cream, 5 = speckled, $6=$ chocolate, $7=$ light brown, $8=$ black, $9=$ mixed, $10=$ dark brown; SCT, seed coat texture, where 1 = smooth and 2 = rough; $\mathrm{GH}$, growth habit, where $1=$ bushy, $2=$ erect and $3=$ spreading; Pl, pest infestation, where $0=$ none, $1=$ mild, and $2=$ severe.

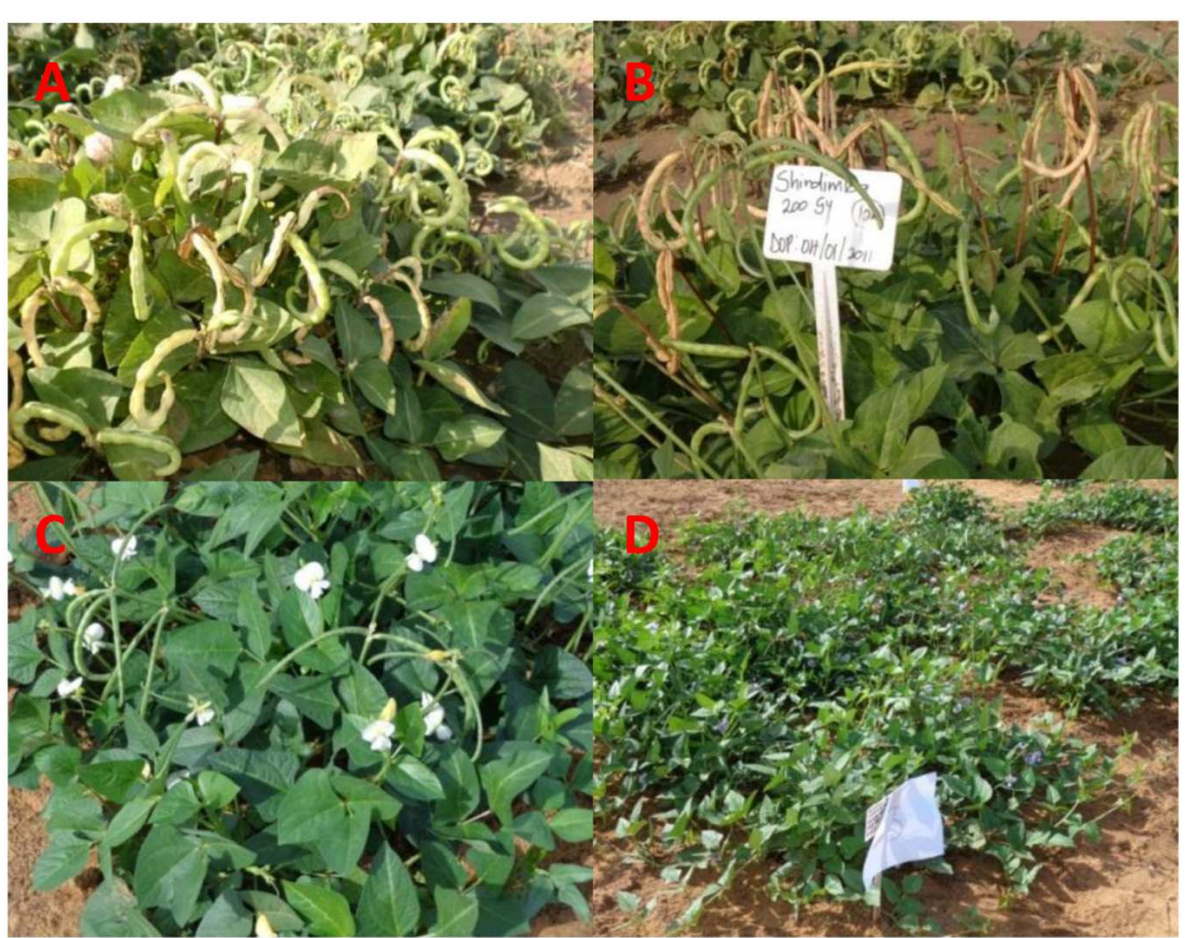

FIGURE 5 | Variation among Shindimba mutant lines. (A) coiled pods, (B) semi-coiled pods observed at Mannheim during the $\mathrm{M}_{2}$ generation, (C) white flower with semi-coiled pods, and (D) Purple flowers observed at Omahenene during the $\mathrm{M}_{5}$ generation. 
TABLE 4 | Quantitative characteristics of $M_{3}$ cowpea mutant lines irradiated at different gamma radiation doses (Gy) in relation to their parental lines/control (Gy 0) observed at Bagani Research Station during 2011/2012 season.

\begin{tabular}{|c|c|c|c|c|c|c|c|c|c|c|c|c|c|c|}
\hline Variety & Dose (Gy) & TNP & ES $\%$ & & DG & DTF & DPS & DMT & NPP & PL & PW & NSP & HSW & SYP \\
\hline \multirow[t]{12}{*}{ Bira } & 0 & 330 & 100 & Min & 3 & 47 & 51 & 57 & 3.0 & 13.0 & 7.0 & 7.6 & 13.0 & 3.0 \\
\hline & & & & Max & 3 & 58 & 63 & 74 & 57.0 & 20.6 & 136 & 18.0 & 18.0 & 94.0 \\
\hline & & & & Mean & 3 & 50 & 55 & 64 & 28.6 & 15.1 & 64.9 & 14.5 & 15.1 & 40.9 \\
\hline & 300 & 330 & 90.6 & Min & 3 & 40 & 49 & 52 & 4.0 & 10.4 & 3.0 & 9.0 & 9.0 & 1.0 \\
\hline & & & & Max & 3 & 80 & 86 & 92 & 5439.0 & 20.0 & 4003.0 & 19.0 & 25.0 & 3500.0 \\
\hline & & & & Mean & 3 & 52 & 58 & 63 & 322.6 & 16.9 & 211.9 & 10.8 & 14.4 & 136.6 \\
\hline & 450 & 330 & 60.6 & Min & N/A & $N / A$ & N/A & N/A & N/A & N/A & N/A & N/A & $\mathrm{N} / \mathrm{A}$ & $\mathrm{N} / \mathrm{A}$ \\
\hline & & & & Max & $\mathrm{N} / \mathrm{A}$ & $\mathrm{N} / \mathrm{A}$ & $\mathrm{N} / \mathrm{A}$ & N/A & $\mathrm{N} / \mathrm{A}$ & N/A & $\mathrm{N} / \mathrm{A}$ & N/A & $\mathrm{N} / \mathrm{A}$ & $\mathrm{N} / \mathrm{A}$ \\
\hline & & & & Mean & $\mathrm{N} / \mathrm{A}$ & $\mathrm{N} / \mathrm{A}$ & $\mathrm{N} / \mathrm{A}$ & N/A & $\mathrm{N} / \mathrm{A}$ & N/A & N/A & N/A & $\mathrm{N} / \mathrm{A}$ & $\mathrm{N} / \mathrm{A}$ \\
\hline & & 330 & 93 & Min & 3 & 46 & 50 & 57 & 1.0 & 5.0 & 1.0 & 1.8 & 4.0 & 1.0 \\
\hline & 600 & & & Max & 3 & 59 & 63 & 74 & 120.0 & 21.3 & 218 & 18.6 & 21.0 & 142.0 \\
\hline & & & & Mean & 3 & 50 & 54 & 63 & 16.4 .0 & 14.9 & 36.6 & 12.2 & 14.9 & 22.0 \\
\hline \multirow[t]{9}{*}{ Nakare } & & 330 & 45.5 & Min & 3 & 11 & 25 & 32 & 11.0 & 14.2 & 11.5 & 5.0 & 16.2 & 1.3 \\
\hline & 0 & & & Max & 3 & 35 & 34 & 43 & 85.0 & 19.6 & 220.6 & 12.0 & 30.5 & 138.8 \\
\hline & & & & Mean & 3 & 20 & 29 & 36 & 51.2 & 15.8 & 106.1 & 7.7 & 25.3 & 59.2 \\
\hline & & 330 & 78.5 & Min & 3 & 10 & 25 & 32 & 3.0 & 6.8 & 2.8 & 2.0 & 11.4 & 0.7 \\
\hline & 100 & & & Max & 3 & 37 & 62 & 65 & 125.0 & 23.5 & 327.8 & 17.2 & 32.1 & 191.2 \\
\hline & & & & Mean & 3 & 19 & 29 & 37 & 32.3 & 16.7 & 65.2 & 9.0 & 23.5 & 32.9 \\
\hline & & 330 & 60.3 & Min & 3 & 43 & 45 & 46 & 3.0 & 5.6 & 3.0 & 1.8 & 6.1 & $\mathrm{~N} / \mathrm{A}$ \\
\hline & 150 & & & Max & 3 & 78 & 95 & 96 & 172.0 & 22.7 & 360.8 & 18.4 & 109 & N/A \\
\hline & & & & Mean & 3 & 52 & 57 & 66 & 39.0 & 14.2 & 67.6 & 10.2 & 15.8 & $\mathrm{~N} / \mathrm{A}$ \\
\hline \multirow[t]{9}{*}{ Shindimba } & & 330 & 69.7 & Min & 3 & 49 & 55 & 60 & 3.0 & 10.0 & 3.0 & 6.3 & 15.0 & 2.0 \\
\hline & 0 & & & Max & 3 & 69 & 75 & 83 & 38.0 & 19.0 & 110.0 & 12.0 & 19.0 & 62.0 \\
\hline & & & & Mean & 3 & 57 & 62 & 70 & 23.0 & 16.0 & 44.7 & 9.5 & 17.5 & 22.2 \\
\hline & & 330 & 36 & Min & 3 & 49 & 54 & 60 & 3.0 & 10.0 & 3.0 & 5.8 & 14.0 & 1.0 \\
\hline & 100 & & & Max & 3 & 84 & 90 & 98 & 40.0 & 21.0 & 110.0 & 16.6 & 25.0 & 118.0 \\
\hline & & & & Mean & 3 & 59 & 63 & 71 & 21.0 & 16.0 & 35.4 & 9.5 & 17.7 & 17.7 \\
\hline & & 330 & 69 & Min & 3 & 15 & 47 & N/A & 2.0 & 1.3 & 1.1 & 3.0 & 8.1 & N/A \\
\hline & 200 & & & Max & 3 & 76 & 98 & N/A & 109.0 & 21.9 & 220.2 & 15.4 & 48.7 & $\mathrm{~N} / \mathrm{A}$ \\
\hline & & & & Mean & 3 & 62 & 68 & N/A & 32.0 & 14.6 & 55.5 & 7.9 & 20.8 & $\mathrm{~N} / \mathrm{A}$ \\
\hline
\end{tabular}

TNP, total number of plants per plot; ES\%, percentage establishment; DG, days to $50 \%$ germination; DTF, days to 50\% flowering; DPS, days to 50\% pod setting; DMT, days to 50\% maturity; NPP, number of pods per plant; PL, pod length (in cm); PW, pod weight (gram), NSP, number of seeds per pod, HSW, 100 seed weight (gram), SYP, seed yield (gram/per plant), and N/A, data not available.

was recorded for Bira at 600 Gy and Nakare 150 Gy (Table 4). At the $\mathrm{M}_{4} 19$ seeds/pod was achieved in the mutants of Bira at $600 \mathrm{~Gy}$ and Shindimba at $100 \mathrm{~Gy}$. At the $\mathrm{M}_{5}$, mutants of Bira derived from 300 and 450 Gy and Nakare 150 Gy recorded 20 seeds/pod, the highest in this trial (Table 5). Hundred seed weight (HSW) at $\mathrm{M}_{3}$ was relatively heavier measured at $109 \mathrm{~g}$ for Nakare mutants derived from 150 Gy (Table 4). At the $\mathrm{M}_{4}$ the higher HSW (115 g) was recorded for Bira at 450 Gy (Table 5). During the $\mathrm{M}_{5}$ Bira displayed higher HSW of $171 \mathrm{~g}$ at 450 Gy (Table 6). High seed yield per plant is an economic trait for cowpea growers. At $\mathrm{M}_{3}$, higher seed yield of $3500 \mathrm{~g}$ per plant was recorded for Bira mutants derived from the mutagenic treatment of 300 Gy (Table 4).
During the $\mathrm{M}_{4}$ generation Bira and Nakare mutants derived from $300 \mathrm{~Gy}$ and $100 \mathrm{~Gy}$ had a relatively higher seed yields of 287 and $199 \mathrm{~g} / \mathrm{plant}$, in that order (Table 5). At the $\mathrm{M}_{5}$ generation Bira mutants yielded 570 g/plant, while Nakare had 298 g/plant when subjected to $450 \mathrm{~Gy}$ and $100 \mathrm{~Gy}$, respectively (Table 6).

\section{DISCUSSION}

The present study revealed the important roles of induced mutations in cowpea breeding. It was evident from this study that increased Gy doses above 150 Gy can be lethal for the cowpea 
TABLE 5 | Quantitative characteristics of $\mathbf{M}_{4}$ cowpea mutant lines irradiated at different gamma radiation doses (Gy) in relation to their parental lines/control (Gy 0) observed at Omahenene Research Station during 2012/2013 season.

\begin{tabular}{|c|c|c|c|c|c|c|c|c|c|c|c|c|c|c|}
\hline Variety & Dose (Gy) & TNP & ES\% & & DG & DTF & DPS & DMT & NPP & PL & PW & NSP & HSW & SYP \\
\hline \multirow[t]{12}{*}{ Bira } & 0 & 330 & 69.7 & Min & 3 & 45 & 49 & 59 & 8.0 & 14.0 & 13.0 & 5.0 & 10.0 & 6.0 \\
\hline & & & & Max & 3 & 48 & 53 & 72 & 88.0 & 20.0 & 231.0 & 20.0 & 16.0 & 187.0 \\
\hline & & & & Mean & 3 & 46 & 50 & 68 & 31.0 & 17.7 & 86.2 & 14.2 & 13.0 & 53.4 \\
\hline & 300 & 330 & 55.0 & Min & 3 & 44 & 48 & 66 & 2.0 & 9.0 & 4.0 & 6.0 & 5.0 & 1.0 \\
\hline & & & & Max & 3 & 51 & 55 & 74 & 97.0 & 21.0 & 325.0 & 18.0 & 79.0 & 287.0 \\
\hline & & & & Mean & 3 & 46 & 50 & 69 & 31.0 & 16.8 & 79.6 & 14.3 & 13.0 & 52.9 \\
\hline & 450 & 330 & 85.7 & Min & 3 & 45 & 49 & 54 & 1.0 & 10.0 & 2.0 & 4.0 & 9.0 & 1.0 \\
\hline & & & & Max & 3 & 81 & 86 & 90 & 127.0 & 16.0 & 330.0 & 20.0 & 115.0 & 195.0 \\
\hline & & & & Mean & 3 & 49 & 54 & 60 & 26.0 & 15.8 & 50.0 & 17.0 & 15.0 & 30.0 \\
\hline & 600 & 330 & 85.0 & Min & 3 & 46 & 50 & 57 & 1.0 & 6.0 & 1.0 & 2.0 & 4.0 & 1.0 \\
\hline & & & & Max & 3 & 59 & 63 & 74 & 124. & 22.0 & 224.0 & 19.0 & 21.0 & 160.0 \\
\hline & & & & Mean & 3 & 50 & 55 & 63 & 18.4 & 16.3 & 41.6 & 13.0 & 15.1 & 25.1 \\
\hline \multirow[t]{9}{*}{ Nakare } & 0 & 330 & 42.0 & Min & 3 & 61 & 66 & 96 & 5.0 & 11.0 & 9.0 & 4.0 & 17.0 & 6.0 \\
\hline & & & & Max & 3 & 74 & 78 & 110 & 32.0 & 19.0 & 85.0 & 17.0 & 26.0 & 62.0 \\
\hline & & & & Mean & 3 & 70 & 75 & 104 & 14.0 & 15.1 & 29.8 & 9.8 & 22.8 & 22.8 \\
\hline & 100 & 330 & 56.0 & Min & 3 & 61 & 66 & 86 & 2.0 & 10.0 & 4.0 & 5.0 & 5.0 & 2.0 \\
\hline & & & & Max & 3 & 78 & 86 & 113 & 70.0 & 21.0 & 227.0 & 14.0 & 59.0 & 199.0 \\
\hline & & & & Mean & 3 & 71 & 76 & 103 & 15.0 & 15.5 & 35.3 & 10.0 & 21.4 & 26.7 \\
\hline & 150 & 330 & 88.8 & Min & 3 & 61 & 67 & 86 & 2.0 & 8.0 & 3.0 & 3.0 & 3.0 & 1.0 \\
\hline & & & & Max & 3 & 79 & 86 & 115 & 85.0 & 26.0 & 287.0 & 18.0 & 40.0 & 131.0 \\
\hline & & & & Mean & 3 & 71 & 76 & 103 & 21.9 & 16.5 & 48.0 & 11.0 & 17.3 & 33.5 \\
\hline \multirow[t]{9}{*}{ Shindimba } & 0 & 330 & 93.9 & Min & 3 & 42 & 68 & 72 & 7.0 & 7.0 & 7.0 & 3.0 & 12.0 & 3.0 \\
\hline & & & & Max & 3 & 75 & 78 & 85 & 44.0 & 29.0 & 123.0 & 13.0 & 30.0 & 91.0 \\
\hline & & & & Mean & 3 & 71 & 72 & 76 & 20.0 & 13.0 & 33.0 & 7.4 & 20.1 & 25.1 \\
\hline & 100 & 330 & 82.4 & Min & 3 & 42 & 66 & 87 & 2.0 & 7.0 & 3.0 & 3.0 & 10.0 & 2.0 \\
\hline & & & & Max & 3 & 80 & 86 & 115 & 63.0 & 23.0 & 130.0 & 19.0 & 30.0 & 91.0 \\
\hline & & & & Mean & 3 & 71 & 76 & 104 & 16.7 & 13.8 & 27.7 & 8.1 & 19.8 & 20.9 \\
\hline & 200 & 330 & 68.5 & Min & 3 & 62 & 66 & 94 & 1.0 & 9.0 & 3.0 & 3.0 & 6.0 & 2.0 \\
\hline & & & & Max & 3 & 80 & 86 & 115 & 59.0 & 31.0 & 123.0 & 16.0 & 30.0 & 91.0 \\
\hline & & & & Mean & 3 & 72 & 76 & 104 & 15.5 & 13.0 & 26.5 & 8.1 & 18.4 & 19.3 \\
\hline
\end{tabular}

TNP, total number of plants per plot; ES\%, percentage establishment; DG, days to $50 \%$ germination; DTF, days to 50\% flowering; DPS, days to 50\% pod setting; DMT, days to 50\% maturity; NPP, number of pods per plant; PL, pod length (in cm); PW, pod weight (gram), NSP, number of seeds per pod, HSW, 100 seed weight (gram), SYP, seed yield (gram/per plant).

breeding line such as Nakare, while a dose above 200 Gy is lethal for the breeding line Shindimba. Other authors have reported the negative effects of increased mutagenic doses affecting various crops' establishment and survival for breeding (Mba et al., 2009).

The present study showed the presence of clear phenotypic differences among the tested mutant lines when compared to their respective controls. Overall, increased irradiation dose was associated with visual phenotypic mutants. Mutants displayed visual phenotypic differences including chlorophyll, leaf, upright single stem, pod, and seed during the $M_{2}$ to $M_{5}$ generations. Chlorophyll mutants observed were plants with yellow and striped leaves, albinos or yellow to pale leaf and stem pigmentations. Virescence mutants showed broad pale green leaf with its margin resembling a spinach leaf (Figure 2). According to Girija and Dhanavel (2009) and Maluszynski et al. (2009), the appearance of chlorophyll defects is a good indicator of genetic action of the mutagen. Singh et al. (2013) reported that increased Gy doses provided higher frequency of chlorophyll mutants in cowpea when compared to other mutagens such as EMS. Girija and Dhanavel (2009) outlined the effectiveness and efficiency of mutagens for selection of mutants with economic traits. The authors suggested that for effective phenotypic selection the mutation treatment should not yield unintended damages including chromosomal aberrations, physiological and toxic effects, which reduce cell survival and ultimately eliminate the mutation. Despite its negative effects on the early stages of 
TABLE 6 | Quantitative characteristics of $\mathbf{M}_{5}$ cowpea mutant lines irradiated at different gamma radiation doses (Gy) in relation to their parental lines/control observed at Omahenene Research Station during 2013/2014 season.

\begin{tabular}{|c|c|c|c|c|c|c|c|c|c|c|c|c|c|c|}
\hline Variety & Dose (Gy) & TNP & ES $\%$ & & DG & DTF & DPS & DMT & NPP & PL & PW & NSP & HSW & SYP \\
\hline \multirow[t]{12}{*}{ Bira } & 0 & 330 & 97.0 & Min & 3 & 68.0 & 73.0 & 98.0 & 7.0 & 16.0 & 15.0 & 6.0 & 9.0 & 10.0 \\
\hline & & & & Max & 3 & 83.0 & 88.0 & 115.0 & 66.0 & 27.0 & 155.0 & 18.0 & 16.0 & 115.0 \\
\hline & & & & Mean & 3 & 74.0 & 78.0 & 102.0 & 40.7 & 21.0 & 88.9 & 14.3 & 12.9 & 61.9 \\
\hline & 300 & 330 & 77.6 & Min & 3 & 64.0 & 69.0 & 98.0 & 3.0 & 13.0 & 6.0 & 5.0 & 4.0 & 3.0 \\
\hline & & & & Max & 3 & 83.0 & 88.0 & 115.0 & 150.0 & 30.0 & 325.0 & 20.0 & 29.3 & 213.0 \\
\hline & & & & Mean & 3 & 73.0 & 78.0 & 102.0 & 30.9 & 21.0 & 66.6 & 14.2 & 12.7 & 47.0 \\
\hline & 450 & 330 & 85.8 & Min & 3 & 42.0 & 46.0 & 66.0 & 2.0 & 13.0 & 6.0 & 5.0 & 11.0 & 3.0 \\
\hline & & & & Max & 3 & 58.0 & 69.0 & 76.0 & 233.0 & 20.0 & 659.0 & 20.0 & 171.0 & 570.0 \\
\hline & & & & Mean & 3 & 47.0 & 51.0 & 70.0 & 31.6 & 17.7 & 81.5 & 14.9 & 16.2 & 60.0 \\
\hline & 600 & 330 & 78.5 & Min & 3 & 37.0 & 42.0 & 62.0 & 1.0 & 9.0 & 1.0 & 3.0 & 4.0 & 2.0 \\
\hline & & & & Max & 3 & 56.0 & 61.0 & 81.0 & 78.0 & 27.0 & 276.0 & 18.0 & 19.0 & 157.0 \\
\hline & & & & Mean & 3 & 46.0 & 50.3 & 68.6 & 19.9 & 16.3 & 43.4 & 13.2 & 12.4 & 28.1 \\
\hline \multirow[t]{9}{*}{ Nakare } & 0 & 330 & 42.0 & Min & 3 & 41.0 & 45.0 & 65.0 & 47.0 & 16.0 & 76.0 & 13.0 & 1.0 & 51.0 \\
\hline & & & & Max & 3 & 53.0 & 57.0 & 79.0 & 46.0 & 21.0 & 72.0 & 12.0 & 298.0 & 51.0 \\
\hline & & & & Mean & 3 & 47.0 & 50.8 & 69.0 & 45.0 & 16.8 & 70.8 & 12.3 & 62.8 & 50.5 \\
\hline & 100 & 330 & 56.4 & Min & 3 & 37.0 & 41.0 & 58.0 & 1.0 & 9.0 & 1.0 & 1.0 & 1.0 & 1.0 \\
\hline & & & & Max & 3 & 57.0 & 60.0 & 80.0 & 144.0 & 23.0 & 375.0 & 18.0 & 81.0 & 298.0 \\
\hline & & & & Mean & 3 & 46.0 & 49.5 & 66.0 & 39.0 & 17.7 & 86.8 & 12.0 & 18.1 & 62.8 \\
\hline & 150 & 330 & 59.7 & Min & 3 & 42.0 & 46.0 & 64.0 & 1.0 & 10.0 & 3.0 & 5.0 & 6.0 & 2.0 \\
\hline & & & & Max & 3 & 53.0 & 57.0 & 73.0 & 110.0 & 28.0 & 317.0 & 20.0 & 82.0 & 209.0 \\
\hline & & & & Mean & 3 & 46.0 & 50.0 & 68.0 & 29.0 & 21.0 & 70.6 & 12.5 & 18.4 & 45.6 \\
\hline \multirow[t]{9}{*}{ Shindimba } & 0 & 330 & 93.9 & Min & 3 & 50.0 & 54.0 & 66.0 & 2.0 & 8.0 & 5.0 & 3.0 & 2.0 & 2.0 \\
\hline & & & & Max & 3 & 55.0 & 59.0 & 73.0 & 88.0 & 20.0 & 127.0 & 11.0 & 29.0 & 90.0 \\
\hline & & & & Mean & 3 & 52.3 & 56.0 & 69.0 & 33.8 & 13.6 & 64.0 & 8.0 & 22.0 & 42.0 \\
\hline & 100 & 330 & 86.7 & Min & 3 & 42.0 & 46.0 & 60.0 & 1.0 & 8.0 & 1.0 & 1.0 & 2.0 & 1.0 \\
\hline & & & & Max & 3 & 67.0 & 70.0 & 89.0 & 122.0 & 25.0 & 392.0 & 18.0 & 29.0 & 208.0 \\
\hline & & & & Mean & 3 & 50.5 & 54.2 & 70.0 & 35.5 & 14.0 & 75.0 & 8.0 & 21.5 & 50.0 \\
\hline & 200 & 330 & 83.6 & Min & 3 & 44.0 & 48.0 & 65.0 & 1.0 & 7.0 & 1.0 & 1.0 & 6.0 & 1.0 \\
\hline & & & & Max & 3 & 67.0 & 71.0 & 91.0 & 89.0 & 29.0 & 193.0 & 18.0 & 25.0 & 93.0 \\
\hline & & & & Mean & 3 & 52.0 & 56.0 & 73.0 & 20.0 & 16.0 & 39.0 & 9.0 & 16.0 & 25.0 \\
\hline
\end{tabular}

TNP, total number of plants per plot; ES\%, percentage establishment; DG, days to 50\% germination; DTF, days to 50\% flowering; DPS, days to 50\% pod setting; DMT, days to 50\% maturity; NPP, number of pods per plant; PL, pod length (in cm); PW, pod weight (gram), NSP, number of seeds per pod, HSW, 100 seed weight (gram), SYP, seed yield (gram/per plant).

crop growth, chlorophyll mutants are important in mutation breeding programs. Tulmann Neto et al. (2011) reported that the chlorophyll mutants were used in evaluation of the genetic effects and sensitivity of various mutagens on crops. These results are in agreement with Goyal and Khan (2010) whose studies indicated that the incidence of chlorophyll mutants were higher with increased Gy doses in earlier selection generations.

In the present study, mutants at the $\mathrm{M}_{2}$ were genetically diverse owing to phenotypic segregation. The genetic diversity assessed in these mutants were tall/dwarf plant heights, early/late maturity, leaf shapes, branching habit, GH, PS, FC, SC and texture, seed weight and yield (Tables 4-6). Both the qualitative and quantitative parameters measured in the study were useful for selection of cowpea mutants. According to Maluszynski et al. (2009), induced genetic polymorphism among initial cells of the sporogenic layer influences the segregation ratio in the $\mathrm{M}_{2}$ generation. However, mutations of cells of somatic tissues are not transferred to the next generation. Gnanamurthy et al. (2012) stipulated that easily detectable mutants characteristics are phenotypically visible and morphologically distinct with qualitatively inherited genetic changes. These changes occur due to the effect of few major genes or oligogenes yielding macro mutations. In this study, some macro mutations observed were the changes in flower and SC. Micro mutations are the result of polygenes each with minor genetic effect showing quantitative inheritance. The effect and inheritance of minor genes is detected 
using quantitative genetic parameters and statistical methods (Singh et al., 2006). In the current study, short plant height and one seed per pod mutants were recorded in all the breeding lines mostly at the $\mathrm{M}_{3}$ generation. Single seeded pods were also reported by Girija and Dhanavel (2009).

In the present study, other main phenotypic changes observed were increased NMB especially in mutants with spreading $\mathrm{GH}$. Mutants with bushy $\mathrm{GH}$ had reduced number of branches per plant. These characters are indicated to be associated with some physiological properties of the plant including leaf senescence and indeterminate GH (Hall, 2004; Martins et al., 2014). It is reported that characteristics altered through mutation breeding can be combined through the conventional breeding to improve crop performance and drought adaptation (Ehlers and Hall, 1997). The present study found that Nakare mutants had a maximum of 23 main branches per plant, while the comparative control had nine main branches (Table 3 ). According to previous studies (Singh et al., 2003, 2013), the spreading and semi-spreading cowpea types yielded less grain and more fodder when planted in closer spaced rows. The present study found that mutation treatment did not significantly affect the number of days taken to germination, hence all the breeding lines germinated 3 days after planting (Tables 3-6). The mutation treatment had positive effect on the number of days taken to $50 \%$ flowering whereby some of the breeding lines flowered 11 days before the control. Bira mutants subjected to irradiation of $300 \mathrm{~Gy}$ flowered 80 days after planting (Table 3). Maluszynski et al. (2009) suggested that a high dose of a mutagen should yield delayed maturity. Dhanavel et al. (2008) repooted that mutagenesis resulted into variation in plant development including the number of days taken to maturity. According to
Singh et al. (2003), these variations are important to the farmers and the breeders allowing choices of planting time. The breeder will have a choice from a larger breeding stock for various breeding traits and purposes.

Significant observations made in the present study were increased PL and seed yield measured during the $M_{3}$ to $M_{5}$ in all the breeding lines. Goyal and Khan (2010) reported that mutations caused increased PL in some of the cowpea lines. Pod size may contribute to increased seed yield. The number of grains per pod increases with increased PL though this may be associated with reduced total biomass (Singh et al., 2003). Other major effects of the mutation observed in the present study were the range of variations in SC. A mosaic of SCs were noted including white, brown, chocolate, red, speckled, cream, and black. Dhanavel et al. (2008) reported various SCs due to mutational events. The present findings suggested that the NMB per plant, NPP, number of grains per pod, 100seed weight and seed yield per plant reduced significantly with increased concentration of irradiation doses. These findings are in agreement to the studies of Girija and Dhanavel (2009), who reported that mutagenesis is associated with negative and positive phenotypic effects for selection.

The present study demonstrated that most characters of cowpea which are of interest to plant breeders can be altered through mutations using the gamma irradiation technique. Furthermore, new plant attributes were created in the high yielding and well adapted local cowpea varieties. Various pests were observed on mutant cowpea during this study Figure 6. Therefore, there is a need to breed for insect pest tolerance in cowpea. Timko et al. (2007) suggested that the future of cowpea improvement programs should focus on breeding

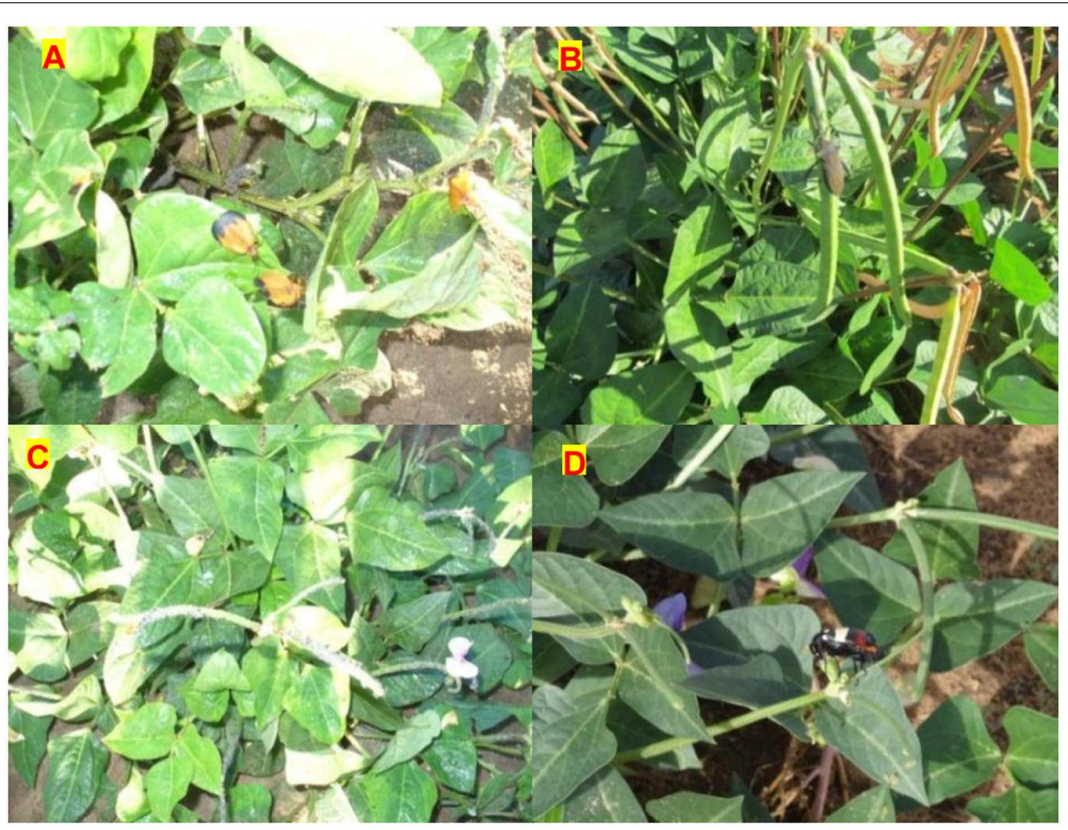

FIGURE 6 | Common insect pests (A) Spiny brown bugs Clavigralla sp., (B) Coreid bug Anoplocnemis curvipes, (C) Aphids Aphis craccivora Koch and Blister (D) Beetle Mylabris phalerata observed among the $M_{5}$ mutants at Bagani, and Omahenene Research Stations concurrently. 
for pests and diseases resistance and other desirable traits such as early maturity, photoperiod insensitivity, suitable plant type, seed quality and yield. Overall, the present study made extensive phenotypic selections of mutants from the $M_{2}$ to $M_{5}$ generations and identified promising genotypes. The selected mutants' are recommended for adaptability and stability tests across representative agro-ecologies for large-scale production or breeding in Namibia or similar environments. The novel cowpea genotypes selected through the study are valuable genetic resources for genetic enhancement and breeding.

\section{AUTHOR CONTRIBUTIONS}

LH and HS designed the research. The experiments were carried out by LH under the supervision of HS. The manuscript was prepared by LH, HS, and HG.

\section{REFERENCES}

Adekola, O., and Oluleye, F. (2007). Induction of genetic variation in Cowpea (Vigna unguiculata L. Walp.) by gamma irradiation. Asian J. Plant Sci. 6, 869-873. doi: 10.3923/ajps.2007.869.873

Bressani, R. (1985). "Nutritive value of cowpea," in Cowpea: Research, Production and Utilization, eds S. R. Singh and K. O. Rachie (New York, NY: John Wiley and Sons).

Ceccarelli, S., and Grando, S. (2007). Decentralized-participatory plant breeding: an example of demand driven research. Euphytica 155, 349-360. doi: 10.1007/s10681-006-9336-8

De Ronde, J. A., and Spreeth, M. H. (2007). Development and evaluation of drought resistant mutant germ-plasm of Vigna unguiculata. Water SA 33, 381-386.

Dhanavel, D., Pavadai, P., Mullainathan, L., Mohana, D., Raju, G., and Girija, M. (2008). Effectiveness and efficiency of chemical mutagens in cowpea (Vigna unguiculata (L.) Walp). Afr. J. Biotechnol. 7, 4116-4117.

Ehlers, J. D., and Hall, A. E. (1997). Cowpea (Vigna unguiculata L. Walp.). Field Crops Res. 53, 187-204. doi: 10.1016/S0378-4290(97)00031-2

Ghaly, A. E., and Alkoaik, F. N. (2010). Extraction of protein from common plant leaves for use as human food. Am. J. Appl. Sci. 7, 331-342. doi: 10.3844/ajassp.2010.331.342

Girija, M., and Dhanavel, D. (2009). Mutagenic effectiveness and efficiency of gamma rays, ethyl methane sulphonate and their combined treatments in cowpea (Vigna unguiculata L. Walp). Global J. Mol. Sci. 4, $68-75$.

Gnanamurthy, S., Mariyammal, S., Dhanavel, D., and Bharathi, T. (2012). Effect of gamma rays on yield and yield components characters R3 generation in cowpea (Vigna unguiculata (L.). Walp.). Int. J. Res. Plant Sci. 2, 39-42.

Goyal, S., and Khan, S. (2010). Induced mutagenesis in Urd bean (Vigna mungo (L.) Hepper): a review. Int. J. Bot. 6, 194-206. doi: 10.3923/ijb.2010. 194.206

Hall, A. E. (2004). Breeding for adaptation to drought and heat in cowpea. Eur. J. Agron. 21, 447-454. doi: 10.1016/j.eja.2004.07.005

Horn, L., and Shimelis, H. (2013). Radio-sensitivity of selected cowpea (Vigna unguiculata) genotypes to varying gamma irradiation doses. Sci. Res. Essays 8, 1991-1997.

International Institute for Tropical Agriculture [IITA] (2004). IITA, Annual Report 2004. Available at: http://www.iita.org/c/document_library/get_file?uuid=9b43 53cd-189f-4a1c-a224-85ee65db18d8\&groupId=25357 (accessed October 23, 2015).

Maluszynski, M. (2001). Officially released mutant varieties - the FAO/IAEA database. Plant Cell Tissue Organ Cult. 65, 175-177. doi: 10.1023/A:1010652523463

Maluszynski, M., Szarejko, I., Bhatia, C. R., Nichterlein, K., and Lagoda, P. J. L. (2009). "Methodologies for generating variability. Part 4: Mutation

\section{FUNDING}

This work was supported by funds from the International Atomic Energy Agency (IAEA) and Ministry of Agriculture, Water and Forestry of Namibia.

\section{ACKNOWLEDGMENTS}

The authors wish to thank the University of KwaZuluNatal and the Ministry of Agriculture, Water and Forestry (MAWF) of the Government of Namibia for the overall research support to the first author. The support from the technical team (Loide Aron, Rose-Marry Hukununa, Kangumba Annethe, and Nghishekwa Alfeus) is highly appreciated.

techniques," in Plant Breeding and Farmer Participation, eds S. Ceccarelli and E. Weltzien (Rome: Food and Agriculture Organization of the United Nations), 159-194.

Martins, C. M., Lawlor, D. W., Quilambo, O. A., and Kunert, K. J. (2014). Evaluation of four Mozambican cowpea landraces for drought tolerance. S. Afr. J. Plant Soil 31, 87-91. doi: 10.1080/02571862.2014. 907453

Mba, C., Afza, R., Bado, S., and Jain, S. M. (2010). "Induced mutagenesis in plants using physical and chemical agents," in Plant Cell Culture: Essential Methods, eds M. R. Davey and P. Anthony (Chichester: John Wiley and Sons), $111-130$.

Mba, C., Afz, R., Jankowicz-Cieslak, J., Bado, S., Matijevic, M., Huynh, O., et al. (2009). "Enhancing genetic diversity through induced mutagenesis in vegetatively propagated plants," in Proceedings International Symposium Induced Mutations in Plants: Induced Plant Mutations in the Genomics Era, 11-15 August 2008, Vienna.

Ng, O., and Marachel, R. (1985). “Cowpea taxonomy, origin, and germplasm," in Cowpea Research, Production and Utilization, eds S. R. Singh and K. O. Rachie (Chichester: John Wiley and Sons), 13-21.

Nielen, S. (2004). FAO/IAEA mutant variety database. Mutation plant breeding, IAEA/FAO vienna. Plant Cell Tissue Organ Cult. 65, 175-177.

SAS (2002). SAS Institute Inc., SAS 9.1.3 Help and Documentation. Cary, NC: SAS Institute Inc.

Singh, B. B., Ajeigbe, H. A., Tarawali, S. A., Fernandez-Rivera, S., and Abubakar, M. (2003). Improving the production and utilization of cowpea as food and fodder. Field Crops Res. 84, 169-177. doi: 10.1016/S0378-4290(03)00148-5

Singh, D. P., Sharma, S. P., Lal, M., Ranwah, B. R., and Sharma, V. (2013). Induction of Genetic variability for polygentraits through physical and chemical mutagens in cowpea (Vigna unguiculata). Legume Res. 36, 10-14.

Singh, V., Ramkrishna, K., and Arya, R. K. (2006). Induced chemical mutagenesis in cowpea [Vigna unguiculata (L.) Walp.]. Indian J. Genet. Plant Breed. 66, 312-315.

Steele, W. M. (1972). Cowpea in Africa. Doctoral thesis, University of Reading, Reading.

Timko, M. P., Ehlers, J. D., and Roberts, P. A. (2007). “Cowpea, pulses, sugar and tuber crops," in Genome Mapping and Molecular Breeding in Plants, ed. C. Kole (Heidelberg: Springer-Verlag Berlin), 49-67.

Tshilenge-Lukanda, L., Funny-Biola, C., Tshiyoyi-Mpunga, A., Mudibu, J., NgoieLubwika, M., and Mukendi-Tshibingu, R. (2012). Radio-sensitivity of some groundnut (Arachis hypogaea L.) genotypes to gamma irradiation: indices for use as improvement. Br. J. Biotechnol. 3, 169-178. doi: 10.9734/BBJ/2012/1459

Tulmann Neto, A., Ando, A., Figueira, A., Latado, R. R., dos Santos, P. C., Correa, L. S., et al. (2011). Genetic improvement of crops by mutation techniques in Brazil. Plant Mutat. Rep. 2, 24-37.

Udensi, O., Arong, G., Obu, J., Ikpeme, E., and Ojobe, T. (2012). Radio-sensitivity of some selected landraces of pulses to gamma irradiation: indices for use as improvement and preservation techniques. Am. J. Exp. Agric. 2, 320-335. 
Wani, M. R. (2006). Estimates of genetic variability in mutated populations and the scope of selection for yield attributes in Vigna radiata (L.) Wilczek. Egypt. J. Biol. 8, 1-6.

Conflict of Interest Statement: The authors declare that the research was conducted in the absence of any commercial or financial relationships that could be construed as a potential conflict of interest.
Copyright $\odot 2016$ Horn, Ghebrehiwot and Shimelis. This is an open-access article distributed under the terms of the Creative Commons Attribution License (CC BY). The use, distribution or reproduction in other forums is permitted, provided the original author(s) or licensor are credited and that the original publication in this journal is cited, in accordance with accepted academic practice. No use, distribution or reproduction is permitted which does not comply with these terms. 